\title{
DOI: http://dx.doi.org/10.33846/2trik9401
}

\section{Korelasi Asupan Zat Besi, Protein, Vitamin C dan Mual Muntah dengan Kejadian Anemia pada Ibu Hamil Trimester I}

\author{
Karwati \\ Prodi D3 Kebidanan STIKes Budi Luhur Cimahi; karwatidk@gmail.com (koresponden) \\ Damai Yanti \\ Prodi D3 Kebidanan STIKes Budi Luhur Cimahi
}

\begin{abstract}
Anemia is one of the many problems that occur in pregnant women in developing countries. First trimester pregnant women often experience nausea and vomiting that can affect the pattern of eating that is received. The purpose of this study was to determine whether nutritional intake and nausea and vomiting disorders in first trimester pregnant women were associated with anemia. The sample of this study was all first trimester pregnant women, selected by quota sampling technique. The research design used in this study was cross sectional, which aims to examine the correlation between nutrient intake (iron, protein, and vitamin $C$ ) and nausea and vomiting disorders with anemia. The instrument used to determine the intake of iron, protein, vitamin $C$ was food records that were filled by respondents for 3 days. To test the hypothesis of the relationship used the chi square test and Fisher's exact test. From the results of the analysis of the relationship between iron intake, Vitamin $C$ and nausea and vomiting with anemia, $p$-value $=0.003$, p-value $=0.001$ and p-value 0.001, it can be concluded that there is a relationship between iron intake, vitamin $C$ and vomiting nausea with the incidence of anemia in first trimester pregnant women (first). While the results of the analysis of the relationship of protein intake with anemia obtained p-value $=0.806$, it can be concluded that there is no relationship between protein intake and the incidence of anemia in first trimester pregnant women (first). The mean intake of iron, protein, and vitamin $C$ in first trimester pregnant women both in the anemic and non-anemic groups had a daily intake that was still far from the nutritional adequacy standard set by the government that the RDA of iron was $26 \mathrm{~g} / \mathrm{dL} /$ day Protein was $76 \mathrm{mg} /$ day and Vit C is 70-85 mg / day.
\end{abstract}

Keywords: food intake; nausea and vomiting; anemia

\begin{abstract}
ABSTRAK
Anemia merupakan salah satu masalah yang banyak terjadi pada ibu hamil di negara berkembang. Ibu hamil trimester I sering mengalami gangguan mual muntah yang dapat berpengaruh pada pola ragam makan yang diterima. Tujuan dari penelitian ini adalah mengetahui apakah asupan nutrisi dan gangguan mual muntah pada ibu hamil trimester I berhubungan dengan kejadian anemia. Sampel penelitian ini adalah seluruh ibu hamil trimester I diambil dengan teknik Non Probability sampling yaitu Sampling Kuota. Desain penelitian yang digunakan dalam penelitian ini adalah epidemiologi analitik observasional dengan desain cross sectional, yang bertujuan menguji hipotesi dalam mencari korelasi asupan nutrisi (zat besi, protein, dan vitamin C) dan gangguan mual muntah dengan kejadian anemia. Instrumen yang digunakan untuk mengetahui kecukupan asupan zat besi, protein, vitamin $\mathrm{C}$ adalah food records yang di isi oleh responden selama 3 hari. Untuk melihat hubungan karakteristik dengan variabel dependen digunakan uji chi square dengan alternative uji exact fisher. Dari hasil analisis hubungan antara asupan zat besi, Vitamin $\mathrm{C}$ dan mual muntah dengan anemia didapatkan nilai $\mathrm{p}$-value $=0,003$, $\mathrm{p}$-value $=0,001$ dan p-value 0,001 maka dapat disimpulkan bahwa ada hubungan antara asupan Zat Besi, Vitamin C dan Mual Muntah dengan kejadian Anemia pada ibu hamil trimester 1 (pertama). Sedangkan hasil analisis hubungan asupan protein dengan anemia didaparkan p-value =0,806 maka dapat disimpulkan bahwa tidak ada hubungan antara asupan protein dengan kejadian anemia pada ibu hamil trimester 1 (pertama). Rerata asupan zat besi, protein, dan vitamin $\mathrm{C}$ pada ibu hamil trimester I baik pada kelompok anemia maupun tidak anemia memiliki jumlah asupan harian yang masih jauh dari standar kecukupan gizi yang ditetapkan oleh pemerintah bahwa AKG zat besi adalah $26 \mathrm{~g} / \mathrm{dL} / \mathrm{hari}$ Protein adalah $76 \mathrm{mg} / \mathrm{hari}$ dan Vit C adalah $70-85 \mathrm{mg} / \mathrm{hari}$.
\end{abstract}

Kata kunci: asupan makanan; mual dan muntah; anemia

\section{PENDAHULUAN}

Anemia merupakan salah satu masalah yang banyak terjadi pada ibu hamil di negara berkembang. World Health Organization (WHO) memperkirakan $40 \%$ kematian ibu berkaitan dengan anemia dalam kehamilan. ${ }^{(15)}$ Berdasarkan data WHO tahun 1993-2005, prevalensi anemia pada ibu hamil sebesar 34\% dan sekitar 75\% berada di negara berkembang. ${ }^{(16)}$ Prevelensi anemia di Indonesia berdasarkan hasil Riset Kesehatan Dasar (Riskesdas) tahun 2013 sebesar 37,1\%. Anemia pada ibu hamil sebagai penyulit kehamilan merupakan masalah 
yang perlu diatasi dengan baik. Anemia diketahui berhubungan dengan perdarahan sebagai penyebab kematian pada ibu bersalin. Anemia pada kehamilan membutuhkan pengelolaan yang terpadu termasuk perilaku konsumsi makan ibu. Zat besi sangat di butuhkan untuk pembentukan hemoglobin. Zat besi di dalam tubuh selalu berikatan dengan protein. Protein mempunyai peranan penting dalam pembentukan hemoglobin dan transportasi zat besi, sedangkan vitamin $\mathrm{C}$ berperan dalam membantu meningkatkan penyerapan zat besi terutama besi non heme. Proses penyerapan vitamin C akan efektif jika dikonsumsi bersamaan dengan konsumsi sumber zat besi non heme. Pada ibu hamil trimester I sering mengalami gangguan mual muntah yang dapat berpengaruh pada pola ragam makan yang diterima. Pada kasus yang lebih berat gangguan ini dapat menyebabkan hiperemesis gravidarum yang dapat mengakibatkan ibu hamil mengalami gangguan nutrisi berat. Beberapa faktor yang secara tidak langsung dapat penyebabkan terjadinya anemia antara lain status ekonomi, pendidikan, usia, paritas, dan status gizi ibu dengan IMT. Mengingat besarnya risiko anemia pada ibu hamil maka penulis ingin mengetahui apakah asupan nutrisi dan gangguan mual muntah pada ibu hamil trimester I berhubungan dengan kejadian anemia.

\section{METODE}

Desain penelitian yang digunakan dalam penelitian ini adalah epidemiologi analitik observasional dengan desain cross sectional, yang bertujuan menguji hipotesi dalam mencari korelasi asupan nutrisi (zat besi, protein, dan vitamin C) dan gangguan mual muntah dengan kejadian anemia. Instrumen yang digunakan untuk mengetahui kecukupan asupan zat besi, protein, vitamin $\mathrm{C}$ adalah food records yang di isi oleh responden selama 3 hari. Untuk melihat hubungan karakteristik dengan variabel dependen digunakan uji chi square dengan alternative uji exact fisher.

\section{HASIL}

Penelitian mengenai korelasi asupan zat besi, protein, vitamin $\mathrm{C}$, dan gangguan mual muntah dengan kejadian anemia pada ibu hamil trimester I di lakukan di Kota Cimahi. Subjek pada penelitian ini adalah ibu hamil trimester I yang dipilih dari 3 BPM (Bidan Praktik Swasta) di Wilayah Kerja Puskesmas Cimahi Tengah, Puskesmas Cimahi Selatan dan Puskesmas Cimahi Utara. Jumlah responden yang direncanakan sebanyak 200 ibu, tetapi pada waktu pengambilan data yang dilakukan 4 bulan berturut-turut hanya 115 Ibu Hamil yang usia kehamilanya sesuai dengan kriteria yaitu trimester I (pertama).

Hasil univariabel dalam penelitian ini meliputi prevalensi anemia pada ibu hamil trimester I yang disajikan dalam tabel 1 .

Table 1. Kejadian anemia pada ibu hamil trimester I

\begin{tabular}{|c|c|c|}
\hline Kejadian anemia & $\mathrm{n}=103$ & $\%$ \\
\hline Anemia & 35 & 31.5 \\
\hline Tidak anemia & 76 & 68.5 \\
\hline
\end{tabular}

Kejadian anemia pada ibu hamil trimester I berjumlah 35 ibu dengan nilai rerata kadar hemoglobin $(\mathrm{Hb})$ pada kelompok anemia sebesar $10.3 \mathrm{~g} / \mathrm{dL}$. Pemeriksaan kadar Hb dengan menggunakan HB digital yang dilakukan oleh peneliti tercantum pada tabel 2.

Table 2. Perbandingan nilai Hb pada ibu hamil yang anemia dan tidak anemia

\begin{tabular}{|c|c|c|}
\hline \multirow{2}{*}{ Kadar hemoglobin } & \multicolumn{2}{|c|}{ Anemia } \\
\cline { 2 - 3 } & Ya $(\mathrm{n}=35)$ & Tidak $(\mathrm{n}=76)$ \\
\hline Mean & 10.3 & 12,6 \\
\hline SD & 0.42 & 1.03 \\
\hline Minimal-Maksimal & $9.4-10.9$ & $11-14.8$ \\
\hline
\end{tabular}

Selanjutnya, karakteristik ibu yang meliputi usia, pendidikan, sosial ekonomi, paritas dan indeks masa tubuh (IMT) disajikan pada tabel 3.

Berdasarkan hasil analisis uji Chi-square pada tabel 3 terlihat bahwa karakteristik ibu yang terdiri dari usia didapatkan nilai $p$ value 0.717 , pendidikan didapatkan nilai $p$ value 0.239 , sosial ekonomi didapatkan nilai $p$ value 0.196, paritas didapatkan nilai $p$ value 0.144, dan IMT didapatkan nilai $p$ value 0.569, maka dapat disimpulkan bahwa karakteristik ibu yang terdiri dari usia, pendidikan, sosial ekonomi, paritas dan IMT tidak mempunyai hubungan yang bermakna dengan kejadian anemia ( $p>0,05)$. 
Table 3. Perbandingan karakterisitik ibu hamil trimester I pada kelompok anemia dan tidak anemia

\begin{tabular}{|c|c|c|c|}
\hline \multirow{2}{*}{ Karakteristik } & \multicolumn{2}{|c|}{ Anemia } & \multirow{2}{*}{ Nilai P* } \\
\hline & $Y a(n=35)$ & Tidak $(n=76)$ & \\
\hline \multicolumn{4}{|l|}{ Usia (tahun) } \\
\hline Berisiko $(<20$ dan $>35)$ & $6(17.1 \%)$ & $11(14.5 \%)$ & \multirow[t]{2}{*}{0,717} \\
\hline Tidak berisiko (20-35) & $29(82.9 \%)$ & $65(85.5 \%)$ & \\
\hline \multicolumn{4}{|l|}{ Pendidikan } \\
\hline Dasar & $7(20 \%)$ & $21(27.6 \%)$ & \multirow[t]{3}{*}{0.239} \\
\hline Menengah & $23(, 65.7 \%)$ & $37(48.7 \%)$ & \\
\hline Tinggi & $5(14.3 \%)$ & $18(23.7 \%)$ & \\
\hline \multicolumn{4}{|l|}{ Sosial Ekonomi } \\
\hline Dibawah rata-rata UMR Kota & $23(65.7 \%)$ & $40(52.6 \%)$ & \multirow[t]{2}{*}{0.196} \\
\hline Diatas rata-rata UMR Kota & $12(32.3 \%)$ & $36(47.4 \%)$ & \\
\hline \multicolumn{4}{|l|}{ Paritas } \\
\hline Berisiko $(<1$ dan $>3)$ & $8(22.9 \%)$ & $28(36.8 \%)$ & \multirow[t]{2}{*}{0.144} \\
\hline Tidak berisiko & $27(77.1 \%)$ & $48(63.1 \%)$ & \\
\hline $\operatorname{IMT}\left(\mathrm{kg} / \mathrm{m}^{2}\right)$ & & & 0,569 \\
\hline Kurus $(<18,5)$ & $3(8.6 \%)$ & $6(7.9 \%)$ & \\
\hline Normal $(18,5-24,9)$ & $26(72.3 \%)$ & $50(65.8 \%)$ & \\
\hline Berlebih $(\geq 25)$ & $6(17.1 \%)$ & $20(26.3 \%)$ & \\
\hline
\end{tabular}

Ket: *Uji Chi-square

Sebelum menganalisis korelasi asupan zat besi, protein, vitamin C, dan gangguan mual muntah dengan kejadian anemia pada ibu hamil trimester I, peneliti sajikan terlebih dahulu data univariabel asupan nutrisi yang terdiri asupan zat besi, protein, dan vitamin $\mathrm{C}$ tersebut dibandingkan dengan AKG yang terlihat dalam tabel 4 .

Tabel 4. Perbandingan asupan zat besi, protein, dan vitamin C dengan AKG (Angka Kecukupan Gizi)

\begin{tabular}{|c|c|c|c|}
\hline \multirow{2}{*}{ Asupan Gizi $(\mathrm{mg})$} & \multicolumn{2}{|c|}{ Kadar Asupan Anemia } & \multirow{2}{*}{ AKG } \\
\cline { 2 - 3 } & Ya $(\mathrm{n}=35)$ & Tidak $(\mathrm{n}=76)$ & \\
\hline Zat Besi & 1.03 & 8.5 & 26 \\
\hline Protein & 26.6 & 31.7 & 76 \\
\hline Vitamin C & 34.5 & 49.4 & $70-85$ \\
\hline
\end{tabular}

Rerata asupan zat besi, protein, dan vitamin C pada ibu hamil trimester I baik pada kelompok anemia maupun tidak anemia memiliki jumlah asupan harian yang masih jauh dari standar kecukupan gizi yang ditetapkan oleh pemerintah bahwa AKG zat besi adalah $26 \mathrm{gr} / \mathrm{dl} /$ hari Protein adalah $76 \mathrm{mg} / \mathrm{hari}$ dan Vit C adalah $70-85 \mathrm{mg} / \mathrm{hari}$

Peneliti selanjutnya menganalisis korelasi asupan zat besi, protein, vitamin $\mathrm{C}$, dan gangguan mual muntah dengan kejadian anemia pada ibu hamil trimester I yang dilakukan dengan analisis Chi Squere dapat dilihat pada tabel 5 .

Dari hasil analisis hubungan antara asupan zat besi dengan anemia diperoleh bahwa seluruhnya ibu dengan kebutuhan zat besinya tidak terpenuhi mengalami anemia $35(100 \%)$. Hasil uji didapatkan nilai $p$-value $=0,003$ maka dapat disimpulkan bahwa ada hubungan antara asupan zat besi dengan kejadian anemia pada ibu hamil trimester 1 (pertama). Kemudian dari hasil analisis diperoleh OR = 1,246 artinya ibu yang kebutuhan asupan zat besinya tidak terpenuhi mempunyai risiko 1,2 kali mengalami anemia kehamilan dibandingkan dengan ibu yang asupan zat besinya terpenuhi.

Hasil analisis hubungan antara asupan protein dengan anemia diperoleh ada sebanyak $32(91,9 \%) \mathrm{ibu}$ hamil anemia asupan proteinya tidak terpenuhi. Hasil uji didapatkan nilai $p$-value $=0,806$ maka dapat disimpulkan bahwa tidak ada hubungan antara asupan protein dengan kejadian anemia pada ibu hamil trimester 1 (pertama). Kemudian dari hasil analisis diperoleh $\mathrm{OR}=0,595$ artinya ibu yang kebutuhan asupan proteinya tidak terpenuhi mempunyai risiko 0,5 kali mengalami anemia kehamilan dibandingkan dengan ibu yang asupan proteinya terpenuhi.

Hasil analisis hubungan antara asupan Vitamin C dengan anemia diperoleh ada sebanyak $31(88.6 \%) \mathrm{ibu}$ hamil anemia asupan Vitamin $\mathrm{C}$ nya tidak terpenuhi. Hasil uji didapatkan nilai $p$-value $=0,001$ maka dapat disimpulkan bahwa ada hubungan antara asupan vitamin $\mathrm{C}$ dengan kejadian anemia pada ibu hamil trimester 1 
(pertama). Kemudian dari hasil analisis diperoleh $\mathrm{OR}=6,274$ artinya ibu yang kebutuhan asupan Vitamin $\mathrm{C}$ nya tidak terpenuhi mempunyai risiko 6,3 kali mengalami anemia kehamilan dibandingkan dengan ibu yang asupan vitamin $\mathrm{C}$ nya terpenuhi.

Tabel 5. Korelasi asupan zat besi, protein, vitamin C, dan gangguan mual muntah dengan kejadian anemia

\begin{tabular}{|c|c|c|c|c|}
\hline \multirow[b]{2}{*}{ Variable } & \multicolumn{2}{|c|}{ Anemia } & \multirow[b]{2}{*}{ Nilai $p$} & \multirow[b]{2}{*}{ OR } \\
\hline & $\begin{array}{c}\mathrm{Ya} \\
\mathrm{n}=35\end{array}$ & $\begin{array}{l}\text { Tidak } \\
\mathrm{n}=76\end{array}$ & & \\
\hline $\begin{array}{l}\text { Asupan zat besi (mg) } \\
\text { Kebutuhan Terpenuhi } \\
\text { Kebutuhan tidak terpenuhi }\end{array}$ & $\begin{array}{c}0(0 \%) \\
35(100 \%)\end{array}$ & $\begin{array}{l}15(19.7 \%) \\
61(80.3 \%)\end{array}$ & $0.003 *$ & $\begin{array}{c}1.246 \\
95 \% \text { CI }(1.114-1.393)\end{array}$ \\
\hline $\begin{array}{l}\text { Asupan protein (mg) } \\
\text { Kebutuhan Terpenuhi } \\
\text { Kebutuhan tidak terpenuhi }\end{array}$ & $\begin{array}{c}3(8.6 \%) \\
32(91.4 \%\end{array}$ & $\begin{array}{c}4(5.3 \%) \\
72(94.7 \%)\end{array}$ & $0,806^{*}$ & $\begin{array}{c}0.593 \\
95 \% \text { CI }(0.125-2.803)\end{array}$ \\
\hline $\begin{array}{l}\text { Asupan vitamin C (mg) } \\
\text { Kebutuhan Terpenuhi } \\
\text { Kebutuhan tidak terpenuhi }\end{array}$ & $\begin{array}{c}4(11.4 \%) \\
31(88.6 \%)\end{array}$ & $\begin{array}{l}34(44.7 \%) \\
42(55.3 \%)\end{array}$ & $0.001 *$ & $\begin{array}{c}6.274 \\
95 \% \text { CI }(2.016-19.523)\end{array}$ \\
\hline $\begin{array}{l}\text { Gangguan mual muntah } \\
\text { Tidak mual muntah } \\
\text { Mual } \\
\text { Mual dan muntah }\end{array}$ & $\begin{array}{c}2(6.5 \%) \\
19(35.8 \%) \\
14(51.9 \%)\end{array}$ & $\begin{array}{l}29(93.5 \%) \\
34(64.2 \%) \\
13(48.1 \%)\end{array}$ & $0.001 *$ & - \\
\hline
\end{tabular}

Hasil analisis hubungan antara mual muntah dengan anemia diperoleh ada sebanyak $19(35,8 \%)$ ibu hamil anemia mengalami mual. Hasil uji didapatkan nilai $p$-value $=0,001$ maka dapat disimpulkan bahwa ada hubungan antara mual muntah dengan kejadian anemia pada ibu hamil trimester 1 (pertama).

\section{PEMBAHASAN}

\section{Korelasi Asupan Zat Besi, Protein, Vitamin C dan Gangguan Mual Muntah dengan Kejadian Anemia}

Asupan nutrisi dalam penelitian ini dinilai dengan menggunakan lembar food records yang diisi oleh responden selama 3 hari berturut-turut dan didapatkan hasil uji statistik sesuai tabel 4 bahwa angka kecukupan asupan zat besi, protein, vitamin $\mathrm{C}$ dalam penelitian ini baik yang mengalami anemia maupun tidak anemia masih kurang dari yang dianjurkan oleh pemerintah dimana AKG untuk zat besi adalah $26 \mathrm{mg} /$ hari, untuk protein $76 \mathrm{mg} /$ hari sedangkan untuk vitamin C 70-85 mg/ hari. Setelah dilakukan uji statistik pada tabel 5 terlihat bahwa terdapat korelasi yang bermakna antara asupan zat besi, vitamin $\mathrm{C}$ dengan kejadian anemia sedangkan untuk korelasi antara protein dengan anemia didapatkan hasil tidak ada korelasi antara asupan protein dan anemia. Hasil penelitian ini sejalan dengan penelitian Wallace LJ, dkk di Kamboja yang menunjukkan bahwa konsumsi makanan harian belum memenuhi asupan nutrisi wanita terutama zat besi dan vitamin. $^{(1)}$

Anemia paling banyak terjadi karena kurangnya asupan zat besi yang sangat dibutuhkan oleh ibu hamil dalam proses pembentukan hemoglobin. Tidak semua zat besi digunakan dalam proses metabolisme tubuh, sebagian disimpan sebagai cadangan dalam bentuk ferritin di dalam hati, limpa dan sumsum tulang. Hati merupakan tempat penyimpanan besi terbesar di dalam tubuh, dengan kapasitas penyimpanan besi mencapai 20$30 \%$ total besi tubuh. ${ }^{(2)}$ Pada penelitian ini terdapat hubungan bermakna antara asupan zat besi pada ibu hamil trimester I dengan kejadian anemia $(\mathrm{p}=0,003)$ dengan nilai OR 1,246 yang artinya ibu dengan asupan zat besi yang kurang mempunyai potensi 1,2 kali lipat mengalami anemia. Menurut Elvicha dkk, penurunan kadar hemoglobin baru akan terjadi jika cadangan zat besi di dalam tubuh yang tersimpan dalam bentuk ferritin habis atau sudah sangat menurun. ${ }^{(3)}$ Pada sebagian besar ibu yang tidak anemia dalam penelitian ini disinyalir masih memiliki ferritin, sehingga tidak terjadi penurunan hemoglobin dan tidak terjadi anemia, dibandingkan dengan ibu yang mengalami anemia.

Sintesis hemoglobin selain memerlukan zat besi, juga memerlukan protein yang cukup dalam tubuh. Zat besi merupakan komponen utama pembentukan heme, sedangkan protein adalah komponen utama globin pada hemoglobin. Protein berperan dalam transportasi dan penyimpanan zat besi selain itu dalam penyerapan zat besi di usus halus juga dibantu oleh Heme Carrier Protein (HCP1). ${ }^{(4)}$ Saat hamil terjadi peningkatan kebutuhan 
protein yang disebabkan oleh peningkatan volume darah dan pertumbuhan jaringan baru. Jumlah protein yang harus tersedia sampai akhir kehamilan adalah sebanyak 925 gr yang berada dalam jaringan ibu, plasenta, serta janin. Penelitian kohort di Amerika pada 963.676 wanita menunjukkan semakin rendah asupan protein maka akan semakin rendah kadar hemoglobin. ${ }^{(5)}$ Asupan protein yang tidak adekuat dapat mengganggu metabolisme zat besi yang dapat memengaruhi pembentukan hemoglobin sehingga menyebabkan terjadinya anemia. ${ }^{(4)}$

Asupan protein yang harus dipenuhi ibu selama trimester I adalah 77-79 g/hari. Pada tabel 5, ibu yang mengalami anemia memiliki asupan protein 91,4\% tidak terpenuhi, sehingga masih kurang dari angka kecukupan gizi yang dianjurkan. Setelah dilakukan uji statistik ternyata tidak terdapat hubungan asupan protein dengan kejadian anemia ( $p$-value < 0,005). Kemudian dari hasil analisis diperoleh $\mathrm{OR}=0,595$ artinya ibu yang kebutuhan asupan proteinya tidak terpenuhi mempunyai risiko 0,5 kali mengalami anemia kehamilan dibandingkan dengan ibu yang asupan proteinya terpenuhi.

Hal tersebut sejalan dengan Matayane, dkk di Sulawesi Utara yang menyatakan bahwa asupan protein tidak mempunyai hubungan yang bermakna dengan kadar hemoglobin. ${ }^{(6)}$

Selain protein di atas, penyerapan zat besi dipengaruhi oleh bahan penghambat (inhibitor) dan bahan pemicu (promotor) seperti vitamin $\mathrm{C}$, dimana absorpsi zat besi non heme dalam tubuh dapat meningkat apabila terdapat kadar vitamin $\mathrm{C}$ yang cukup. Absorbsi zat besi dalam bentuk non heme meningkat empat kali lipat bila ada vitamin $C .{ }^{(2)}$ Hasil analisis hubungan antara asupan Vitamin $\mathrm{C}$ dengan anemia diperoleh ada sebanyak 31 (88.6\%) ibu hamil anemia asupan Vitamin C nya tidak terpenuhi. Hal ini sesuai dengan penelitian Astriningrum $\mathrm{EP}$, dkk di Indonesia yang menyatakan bahwa konsumsi vitamin $\mathrm{C}$ pada ibu hamil tergolong masih rendah. ${ }^{(7)}$ Hasil uji didapatkan nilai $p$-value $=0.001$ maka dapat disimpulkan bahwa ada hubungan antara asupan vitamin $\mathrm{C}$ dengan kejadian anemia pada ibu hamil trimester 1 (pertama). Kemudian dari hasil analisis diperoleh $\mathrm{OR}=$ 6.274 artinya ibu yang kebutuhan asupan Vitamin $\mathrm{C}$ nya tidak terpenuhi mempunyai risiko 6.3 kali mengalami anemia kehamilan dibandingkan dengan ibu yang asupan vitamin $\mathrm{C}$ nya terpenuhi.

Peranan vitamin $\mathrm{C}$ dalam proses penyerapan zat besi yaitu membantu mereduksi besi ferri $\left(\mathrm{Fe}^{3+}\right)$ menjadi besi ferro $\left(\mathrm{Fe}^{2+}\right)$ di dalam usus halus sehingga mudah diabsorbsi, proses reduksi tersebut akan semakin besar bila berada pada suasana pH 7 didalam usus. Rata-rata absorbsi adalah 90\% untuk konsumsi diantara 20-120 mg/hari. ${ }^{(2)}$ Asupan vitamin $\mathrm{C}$ dalam penelitian ini berhubungan dengan kejadian anemia, hal ini tidak sesuai dengan penelitan yang dilakukan oleh Sahana, yang menyatakan bahwa anemia paling banyak terjadi pada kelompok asupan vitamin yang rendah namun secara statistik tidak terdapat hubungan yang bermakna. $(2),(8),(9),(10)$

Pada trimester I kejadian anemia bisa terjadi akibat adanya mual muntah yang menyebabkan ibu mengalami gangguan nutrisi jika tidak diimbangi dengan pola konsumsi makanan yang benar. Pada penelitian ini kejadian anemia paling banyak terjadi pada kelompok mual muntah sebanyak 51,9\%\%. Secara statistik terdapat korelasi yang bermakna antara gangguan mual muntah dengan anemia $(\mathrm{p}<0,05)$. Gangguan mual muntah menyebabkan penurunan nafsu makan sehingga terjadi penurunan keseimbangan elektrolit dan menyebabkan perubahan metabolisme tubuh. Emesis gravidarum akan bertambah berat menjadi hiperemesis gravidarum menyebabkan ibu muntah terus menerus tiap kali minum maupun makan (tidak bisa makan), akibatnya tubuh bisa lemah, dehidrasi, dan darah menjadi kental (hemokonsentrasi) yang dapat melambatkan peredaran darah yang berarti penyaluran oksigen dan makanan ke jaringan juga ikut berkurang, sehingga dapat menimbulkan anemia bahkan kerusakan jaringan yang dapat membahayakan kesehatan ibu dan janin yang dikandung. ${ }^{(11),(12)}$

Kejadian anemia pada wanita akan meningkat bila terjadi proses kehamilan, karena selama hamil terjadi peningkatan volume darah yang merupakan hasil dari peningkatan volume plasma dan eritrosit (sel darah merah) di dalam tubuh. Peningkatan volume plasma jauh lebih besar sehingga memberikan efek pengenceran darah (Hemodilusi) dan membuat konsentrasi hemoglobin berkurang. Hemodilusi terjadi sejak kehamilan 10 minggu dan mencapai puncaknya pada kehamilan 32-36 minggu. Bila Hb ibu sebelum hamil sekitar $11 \mathrm{~g} / \mathrm{dl}$, maka dengan adanya hemodilusi akan mengakibatkan anemia dengan $\mathrm{Hb}$ menjadi 9,5-10 g/dl pada awal kehamilan. Kejadian anemia ini dapat diperberat dengan adanya mual muntah sehingga asupan nutrisi ibu menjadi kurang dan terhambat. Oleh karena itu, diperlukan upaya peningkatan asupan nutrisi sebelum hamil dan selama hamil bagi ibu hamil untuk mencukupi kebutuhan ibu bukan hanya asupan zat besi, protein, dan vitamin C, juga peningkatan asupan kalori/energi dari karbohidrat dan lemak. ${ }^{(13)}$

Anemia yang tidak dapat ditangani dengan baik dapat membahayakan ibu dan janin, dimana terdapat korelasi yang erat antara anemia pada saat kehamilan dengan kematian janin, abortus, cacat bawaan, berat bayi lahir rendah bahkan dapat mengakibatkan perdarahan pada saat persalinan yang merupakan penyebab utama kematian ibu. ${ }^{(14)}$ 


\section{KESIMPULAN}

\section{Kesimpulan}

Berdasarkan hasil penelitian dan pembahasan serta teori-teori yang mendukung mengenai korelasi asupan zat besi, protein, vitamin $\mathrm{C}$ dan gangguan mual muntah dengan kejadian anemia, maka diperoleh simpulan sebagai berikut:

1) Asupan zat besi berhubungan dengan kejadian anemia pada ibu hamil trimester I

2) Asupan protein tidak berhubungan dengan kejadian anemia pada ibu hamil trimester I

3) Asupan vitamin $\mathrm{C}$ berhubungan dengan kejadian anemia pada ibu hamil trimester I

4) Gangguan mual muntah berhubungan dengan kejadian anemia pada ibu hamil trimester I

\section{Saran}

1) Berdasarkan keterbatasan penelitian yang disebutkan pada pembahasan, perlu dilakukan penelitian lanjutan terkait dengan penyebab anemia yang lebih kompleks sehingga dapat diketahui secara pasti faktor penyebab terjadinya anemia.

2) Subjek pada penelitian ini sebaiknya diamati terus dalam suatu kohort untuk melihat hubungan asupan nutrisi dengan anemia pada kehamilan trimester II dan III.

3) Perlu adanya konseling suplementasi gizi dari mulai prakonsepsi, untuk mengantisipasi defisiensi nutrisi saat hamil, serta komplikasi akibat anemia dalam kehamilan.

\section{DAFTAR PUSTAKA}

1. BAS LJW. Women's nutrient intakes and food-related knowledge in rural Kandal province, Cambodia1. Asia Pacific Journal of Clinical Nutrition. 2014;23(2):263.

2. Almatsier S. Prinsip dasar ilmu gizi (Edisi Revisi): Gramedia Pustaka Utama; 2009;77-104,185-190, 248250.

3. Savitri EN, Fatmawati, Christianto E. Hubungan Asupan Zat Besi, Vitamin C dan Tembaga dengan Kadar Hemoglobin Pada Mahasiswa Angkatan 2014 Fakultas Kedokteran Universitas Riau JOM FK 2015;2(2).

4. Murray Robert K, Granner Daryl K, Rodwell Victor W. Biokimia Harper, Edisi 27. Penerbit Buku Kedokteran, EGC Jakarta. 2009.

5. Walsh T, O'broin SD, Cooley S, Donnelly J, Kennedy J, Harrison RF, et al. Laboratory assessment of iron status in pregnancy. Clinical chemistry and laboratory medicine. 2011;49(7):1225-30.

6. Thomson CA, Stanaway JD, Neuhouser ML, Snetselaar LG, Stefanick ML, Arendell L, et al. Nutrient intake and anemia risk in the women's health initiative observational study. Journal of the Academy of Nutrition and Dietetics. 2011;111(4):532-41.

7. Kurniati TAR, Nurhaedar J. Hubungan asupan zat gizi dengan kejadian anemia pada wanita prakonsepsi di kecamatan Bringkanaya Kota Makasar. Universitas Hasanudin. 2013.

8. Aritonang E. Kebutuhan gizi ibu hamil. Bogor: IPB press kampus IPB Taman Kencana. 2010;89.

9. Astriningrum EP, Hardinsyah H, Nurdin NM. Asupan asam folat, vitamin B12 dan vitamin C pada ibu hamil di indonesia berdasarkan studi diet total. Jurnal Gizi dan Pangan. 2017;12(1):31-40.

10. Sahana ON, Sumarmi S. Hubungan Asupan Mikronutrien dengan Kadar Hemoglobin Pada Wanita Usia Subur (WUS). Media Gizi Indonesia. 2015;10(2):184-91.

11. Prawirohardjo S. Ilmu kebidanan. Jakarta: Yayasan. 2009;774-780.

12. Haidar J. Prevalence of anaemia, deficiencies of iron and folic acid and their determinants in Ethiopian women. Journal of health, population, and nutrition. 2010;28(4):359.

13. Sudikno S, Sandjaja S. Prevalensi Dan Faktor Risiko Anemia Pada Wanita Usia Subur Di Rumah Tangga Miskin Di Kabupaten Tasikmalaya Dan Ciamis, Provinsi Jawa Barat. Jurnal Kesehatan Reproduksi. 2016;7(2):71-82.

14. Hidayati R. Asuhan keperawatan pada kehamilan fisiologis dan patologis: Penerbit Salemba; 2009.

15. BKKBN, BPS, Kemenkes, MEASURE DHS, ICF International, USAID. Survei demografi dan kesehatan Indonesia (SDKI) 2012. 2013.

16. Milman N. Anemia-still a major health problem in many parts of the world! Annals of hematology. 2011;90(4):369-77. 